\title{
A Large Block Heater Test for High Level Nuclear Waste Management
}

W. Lin, D. G. Wilder, J. A. Blink, S. C. Blair,

T. A. Buscheck, R. S. Glass, W. E. Glassley, K. Lee,

R. D. McCright, M. W. Owens, and J. J. Roberts

This paper was prepared for submittal to the

XVIII International Symposium on

the Scientific Basis for Nuclear Waste Management

Kyoto, Japan

October 23-27, 1994

July 1994

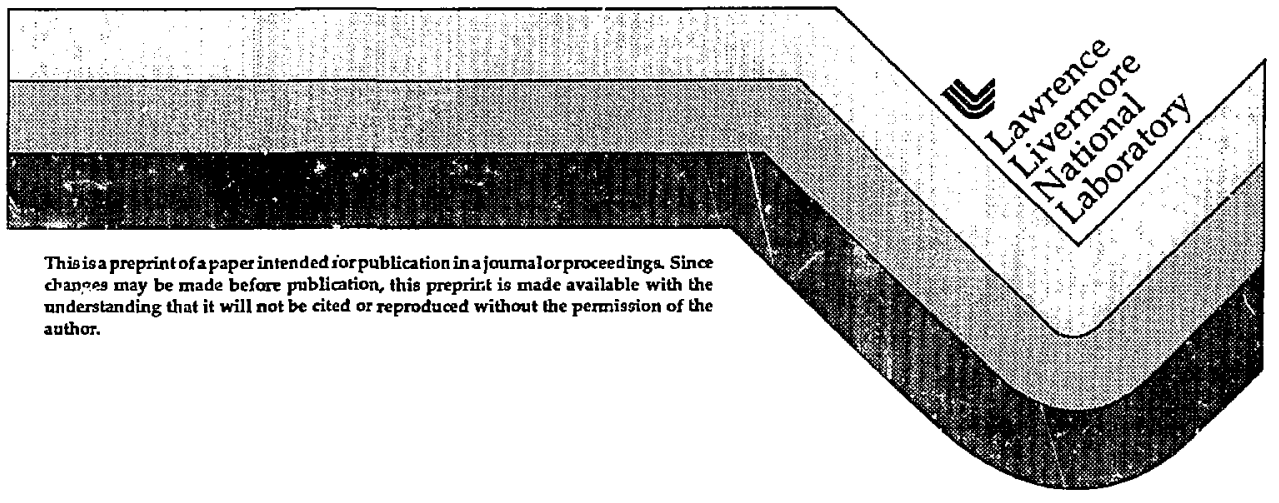




\section{DISCLAIMER}

This document was prepared as an accaunt of wark sponsored by an pgency of the United Slales Government Neither the United States Government nor the University of California nor any of their employeex, makes any warranly, express or implied, or assumes anylegal liabjlity or resporsibility for the wccuracy, completeness, or usefulness

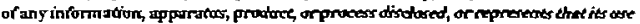
would not infringe privalely owned rights. Reference herrin to any specific commercial products, process, or senice by trade name, trademark, manufacturer, ar otherwise, does not necessarily constilute or imply its endorsement, reeommendation, or fovoring by the United States Govemment or the University of Califimia. The viens and opinions of authors expressed herein do not necessarily state or relect those of the Enites Ststes Governmem or the University of California, and shall nod be used for advertising or product endorsement purposes. 
A LARGE BLOCK HEATER TEST FOR HIGH LEVEL NUCLEAR WASTE MANAGEMENT, Wunan. Lin, D. G. Wilder, J. A. Blink, S. C. Blair, T. A.

Buscheck, R. S. Glass, W. E. Glassley, K. Lee, R. D. McCright, M. W. Owens, and J.

J. Roberts (All at Lawrence Livermore National Laboratory, P.O.Box 808, Livermore, CA 94550)

\section{Abstract}

The radioactive decay heat from nuclear waste packages may, depending on the thernal load, crcate coupled thermal-mechanical-hydrological-chemical (TMHC) processes in the nearfield environment of a repository. A group of tests on a large block (LBT) are planned to provide a timely opportunity to test and calibrate some of the TMHC model concepts. The LBT is advantageous for testing and verifying model concepts because the boundary conditions are coliciolled, and the block can be characterized before and after the experiment. A block of Topopah Spring tuff of about $3 \times 3 \times 4.5 \mathrm{~m}$ will be sawed and isolated at Fran Ridge, Nevada Test Site. Small biocks of the rock adjacent to the large block will be collected for laboratory testing of some individual thermal-mechanical, hydrological, and chemical processes. A constant load of about $4 \mathrm{MPa}$ will be applied to the top and sides of the large block. The sides will be sealed with moisture and thermal barriers. The large block will be heared by heaters within and guard heaters on the sides so that a dry-out zone and a condensate zone will exist simultaneously. Temperature, moisture content, pore pressure, chemical composition, stress, and displacement will be measured throughout the block during the heating and cool-down phases. The results from the experiments on small blocks and the tests on the large block will provide a better understanding of some concepts of the coupled TMHC processes. The progress of the project is presented in this paper.

\section{Introduction}

A major concern for the disposal of high level nuclear wastes in desp geological fomations is the quantity and quality of water that may contact waste packages. The Yucca Mountain Site Characterization Project (YMP) is investigating the Topopah Spring ruff at Yucca Mountain, Nevada, for its surtability as a host rock for the disposal of high level nuclear wastes. The host rock at the potencial repository horizon is a partially saturated, fractured, densely welded, nonlithophysal tuff. Work to date suggests that the host rock at the potential repository horizon has a mean matrix porosity of $14 \%$ and a mean water saturation of $65 \%$ [1]. Therefore, the pores of the host rock are filled with both air and liquid water.

The expected development of the near-ñeld environment in a repository is discussed in the next two paragraphs. The radioactive decay heat from wastc packages will increase the temperanure in the rock mass in the near field of the repository. The temperature in the rock mass depends on the thermal load in the repository. Results from a heater test in G-Tunnel, Nevad 1 Test 
Site ${ }^{[2]}$ and. model calculations [3] indicate that, above an areal power density threshold, the nearfield environment of a nuclear waste repository will consist of a dry-out zone and a condensate zone. The rock in the near field will be subject to thermal loading that may change the fracture porosity and connectivity. Laboratcry studies $[4]$ and a field investigation $\left[\$\left[{ }^{[}\right]\right.$indicate that fractures are the main flow path for vapor/steam. Most of the water vapor will condense where temperatures are sufficiently low. A region of increased saturation is expected to form adjacent to and outside of the drier region due to this condensation. In regions above the heater, for example, the drainage water may be evaporated, flow upward, be condensed, and flow downward again (refluxing) [3]. In regions to the sides of the heaters, the condensed water may be shed [6]. In the condensate region and in the refluxing zone, entanced rock-water interaction may occur. The rock-water interaction will cause dissolution and re-deposition of cerain minerals, which, in $\mathrm{nm}$, will affect the movement of tluids within the rock mass $[7,8,29 ;$. These coupled thermal-mechanicalhydrological-chemical (TMFC) processes have to be understood berore models can provide a meaningful description of the near-field environment and predictions of the quantity and quality of water in the waste package environment.

Experiments are being designed to test, verify, calibrate, and validate some model concepts of the TMHC processes in the laborator; and in the field. A logical experimental sequence begins with experiments on small laboratory scale cores (usually a few centimeters in size), continues with laboratory experiments on small blocks (of a few tens of centimeters in size) and field experiments on a large block (a few meters in size), and ends with in situ field experiments in the Exploratory Studies Facility (ESF) (several tens of meters in size), as shown in Figure 1.
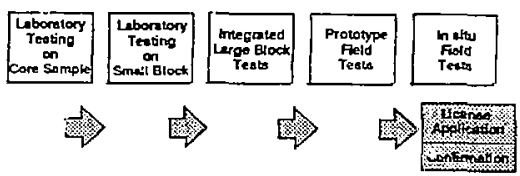

Figure 1. Logical Lesting sequence leading toward license application and confirmation of a repository.

Laboratory tests on small samples of intact rock and samples with single fracture are being corducted to test and develop conceptual models, such as dehydration and rehydration behavior, vapor diffusion, and liquid water imbibition. Larger-scale tests that can incorporate more fractures and inhomogeneities are needed to confirm and validate models. Eventually, in situ field tests in 
the ESF will be performed to confirm models that will be used to predict the performance of an entre repository. Some of the tests shown in Figure 1 may be performed concurrently. This paper presents the progress to date of the large block test (LBT). The LBT is designed to study some of the TMHC processes under controlled boundary conditions [10]. Therefore, it will provide a better and timely understanding of some concepts related to the coupled TMHC processes.

\section{Purpose and Objectives of the LBT}

The LBT is designed to create controlled boundary conditions so that some of the coupled TMHC processes can be observed and some conceprual modeis can be tested. We will monitor. I) dominant heat transfer mechanisms, 2) coincidence (or lack thereof) of the dry-out zone and the boiling-point isotherm, 3) re-wetting of the dry-out zone and the cooling of the region, 4) refluxing of the condensate water above the heated zone, 5) the change of water chemistry in the condensate zone.

The LBT will provide tests on a block of rock which is closer in scale to the repository than previous heater test blocks [11], can be characterized from five exposed surfaces and multiple boreholes, and will be dismantled after testing for further characterization, especially for studying rock-water interactions. The LBT will also provide as opportunity for testing the performance of waste package materials in the heated rock block.

The LBT is expected to meet three objectives:

1) It will improve understanding of the coupled TMHC processes included in models that predict the long-term, near-field pe.formance of a nuclear waste repository.

2) It will provide preliminary data for the development of those models, which will be more rigorously tested under in situ conditions in the Engineered Barrier System Field Tests (EBSFT).

3) It will develop and evaluate measurement systems and techniques to be used in the EBSFT.

The LBT will not replace the EBSFT. Neither will it simulate the in siru conditions in a repository, such as mechanical stresses, mineralogical composition on fracture surfaces, etc. Therefore, the evaluation of testing methodology and instruments will not be complete because the instruments will not be in the environment that will be expected to exist in the ESF.

\section{Description of the LBT}

The LBT consists of two parts: (1) laboratory tests on small blocks of intact rock and blocks with single fractures, quarried from the region adjacent to the large block, to study the thermai hydrological, mechanical, and chemical processes and (2) an attempt at integrated macroscopic simulation and evaluation of the coupled TMHC processes in a large block. 


\section{Block Size Determination and Site Selection}

A block size was chosen to be at least $3 \mathrm{~m}$ on each side and at least $4.5 \mathrm{~m}$ tall. The dimensions were determined by using criteria that will be applied in an analogous way to the EBSFT, that sufficient number of fractures are included in a test region [12] and that it allows for a zone of condensate to form above the coalesced dry-out zone. If fracture densities at Fran Ridge are similar to those in the potential repository horizon, a block of about $3 \mathrm{~m}$ on a side will include at least 10 fractures.

Pre-test calculations have been performed for a block with five horizontal heated holes, each containing a $2.44-\mathrm{m}$-long, 300-wati heating element, spaced by $0.61 \mathrm{~m}$ in a horizontal plane located about $1.5 \mathrm{~m}$ from the bottom of the block. The results of model calculations show (Figure 2) that a dry-out zone of about $0.75 \mathrm{~m}$ immediately above and below the heater plane can be generated after full-power heating for about 4 months with adiabatic conditions on the sides and a constant $20^{\circ} \mathrm{C}$ on the top. The maximum temperature attained is about $135^{\circ} \mathrm{C}$. A condensate zone about $1.25 \mathrm{~m}$ thick will exist adjacent to the dry-out zone.

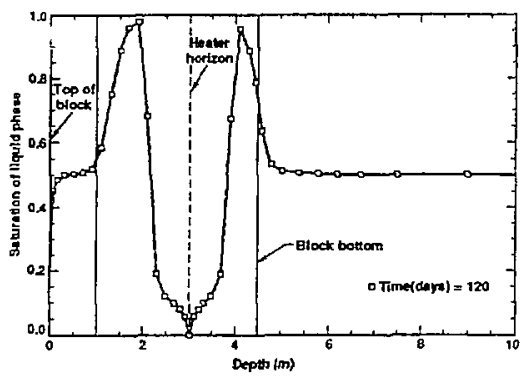

Figure 2. Moisture distribution as a function of depth in the large block, based on the preliminary result of the pre-test model calculation.

We expect that condensate refluxing may occur along fractures in the condensate zone above the heater plane. Based on these calculations a block size of $3 \mathrm{~g} s$ square and $4.5 \mathrm{~m}$ tall was selected. - While a larger block would be desirable, the thickness of load-retaining frame plates becomes excessive for blocks greater than $3 \mathrm{~m}$ in size.

A site at Fran Ridge was selected for the large block. Three considerations were applied in the site selection: the rock type, fracture characteristics, and accessibility. The rock type exposed at Fran Ridge is the same as the densely welded, fractured, Topopah Spring tuff just below the lithoplysal/nonlithophysal contact. The fracture density, as observed on the outcrop, is at least 
one fracture per $30 \mathrm{~cm}$. Both of these two characteristics meet the criteria for a large block site. An outcrop at the southeastem end of Busted Butte, just south of Fran Ridge, was also inspected. The rock type at the Busted Butte site is closer to that at the potential repository horizon, and the fracture density is also similar. But the accessibility of the Fran Ridge site is superior to the Busted Butte site.

Isolation of the Large Block

A belt saw with a $5.79 \mathrm{~m}$-long cutting bar was used to saw four vertical slots that form the boundary of the large block. The rock surrounding the block is being excavated, so that a $3 \times 3 \times$ $4.5 \mathrm{~m}$ block will be free standing, as shown in Figure 3. In order to use the belt saw, a work area of about $12 \times 12 \mathrm{~m}$ was leveled to within $15 \mathrm{~cm}$. A wall of about $4.9 \mathrm{~m}$ in height was created roughly parallel to one of the sides of the block for draining the water used during the sawing. Controlled blasting was used to level the work area. Fractures on the leveled surface were mapped. The block location was chosen, based on the fracture distribution and configuration. In deciding the block location, the stability of the block after the sawing and excavation was the main concern. After locating the block, vertical instrument holes within the block were drilled and cored.

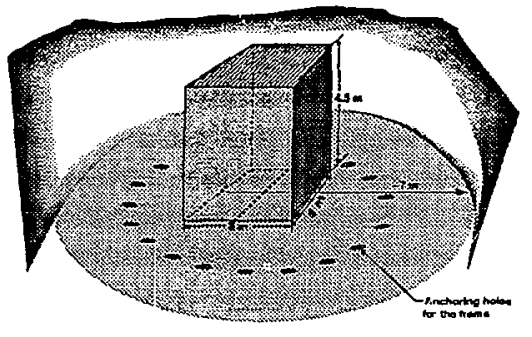

Figure 3. Diagram showing the block and its surrounding area.

Dunnage bags with foam were put in the stis during the sawing to protect the block. $A$ commercial wire saw was used to trim the top of the block. Mechanical excavation is used to remove the rock surrounding the block. The excavation process is on-going. The ground level within the area $1 \mathrm{~m}$ away from the block is now about $3 \mathrm{~m}$ below the top of the block. The block sides are supported by wood blocks with straps as the excavation progresses. Some smaller blocks of rock, about $30 \mathrm{~cm}$ in size, are being collected from the region within $1 \mathrm{~m}$ from the large block for laboratory tests. 


\section{Characterization of the Block}

The large block will be characterized as completely as possible. The distribution of fractures, mineralogical composition of the matrix and the fracture coating, mechanical and bydrological properties, and the initial moisture content will be characterized. The fracture traces on the five surfaces and on the drill cores from the instrument holes will be used to determine the distribution of fractures within the block. The coating on the fractures extending beyond the block will be analyzed, so that the mineralogical composition of the coating on the fractures within the block can be inferred. The properties of the matrix to be determined include porosity, permeability, moisture retention curves, electrical resistivity vs moisture contenh stress-strairs curves, and acoustic wave velocity. The initial moisture content of the block will be determined using neutron logging.

Pre-test modei calculations indicate that the bulk gas permeability of the block should be at least $10^{-15} \mathrm{~m}^{2}$ in order to create a dry-out zone by heating from the heaters within the block. Air injection tests were conducted after the first vertical hole was drilled. Figure 4 shows the air permeability as a function of depth obtained from the single borehole air injection tests. The results indicate that for most parts of the block (in terms of depth) the permeability is above $5 \times 10^{-15} \mathrm{~m}^{2}$. It should be noted that the permeability is dominated by the fractures that intersect the injection hole.

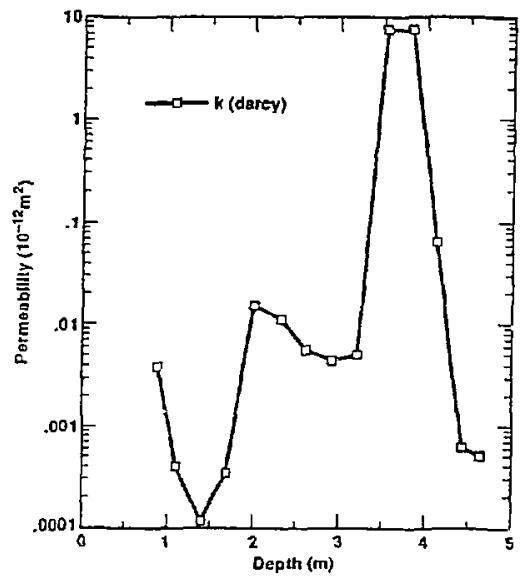

Figure 4. Air permeability as a function of depth in the large block, obtained from a single hole air injecrion tess. 
After all vertical holes were drilled, neutron logging was conducted in some of the holes to estimate the moisture content in the block Neutron logging will be performed later at various stages of the block preparation to estimate the initial moisture content of the block before the experiment starts. According to pre-test model calculations, at least $50 \%$ of the pore volume should be filled with water in order to have enough moisture to create and maintain condensate refluxing. Preliminary analysis of the neutron logging results indicates that more than $50 \%$ of the pore volume is filled with water.

\section{Tests on Small Blocks}

Blocks of Topopah Spring tuff collected during the excavation will be used for laboratory experiments to investigate thermal-hydrological, thermal-chemical, and thermal-mechanical processes. Block assemblies will be constructed by putting together two blocks of the tuff, with sizes up to several tens of centimeters, so trat the two machined surfaces form a controlled aperture. Blocks with a suitable natural fracture will also be used. One block assembly will be used at a time for the experiments. These experiments include: fracture flow vs. matrix imbibition as a function of the fracture aperture, one-dimensional imbibition and dehydration, condensation along fractures, and geomechanical responses to heating. The following paragraphs contain greater detailed explanations of these experiments.

For the fracture flow vs. matrix imbibition experiment, water will be applied to a fracture, and the wetting front will be determined both along the fracture and in the matrix by using electrical resistivity tomography (ERT) [4] and $x$-ray tomography $[13,14]$. The experiment will be done for various fracture apertures and various initial moisture contents, at room temperature, elevated uniform temperature, and under a thermal gradient. Water that flowed through the fracture will be collected for chemical analyses to determine $\mathrm{pH}, \mathrm{Cl}^{-}, \mathrm{HCO}_{3}{ }^{-}, \mathrm{F}^{-}, \mathrm{Si}, \mathrm{Na}, \mathrm{K}$, etc. The fracture surfaces will be exanined before and after the experimem for evidence of rock-water interaction.

In the one-dimensional imbibition experiment, a block assembly with controlled fracture aperture will be brought in contact with water at one end of the fracture. The experiment will be conducted at elevated temperatures. The moisture distribution will be determined using ERT and $x$-ray tomography. The imbibition direction will either be against gravity, with gravity, or perpendicular to gravicy.

There are three types of experiments in the investigation of the dehydration process: onedimensional dehydration in both intact and fractured samples and condensation of vapor along a fracture. In the first two experiments both intact blocks and block assemblies with controlled fracture aperture will be used. The sample will be sealed with a moisture barrier on all of the surfaces except one side, which will serve as the moisture exit from the sample. A sample with known initial moisture content will be heated from the end opposite the open end. Temporal and 
spatial distributions of temperature, moisture content, and pore fluid pressure will be monitored. In the experiment to investigate condensation along a fracture, a thermal gradient will be maintained in the sample so that condensation along the fracture can occur. ERT and x-ray tomography will be used to monitor the moisture distribution in the sample. The fracture surfaces will be examined before and after the experiment for evidence of rock-water interactions.

For the study of thermal-mechanical responses, a block of intact or fractured rock will be put under constant triaxial loads and heated either uniformly or from one end. Stress-strain curves will be determined. Displacement of the matrix and across fractures during the heating phase will be measured. Acoustic emissions will be monitored to detect thermal fracturing. The fracture surfaces will be examined before and after heating for evidence of changes in the fracture properties.

\section{Large Block Tests of the Coupled TMHC Processes}

Tests in the large block will be used to investigate the macroscopic phenomena of the coupled TMHC processes that are affected by multiple fractures, fracture connectivity, scale, and matrix heterogeneities. The large block will first be characterized for its fracture intensity and configuration, as described earlier. Horizontal heater holes and instrument holes will be drilled. Figure 5 shows the instrum at holes and heater holes in the block. Instruments will aiso be installed outside the holes. Installation of instruments, data acquisicicas, test procedures, and data analyses will be discussed next.

\section{(1) Installation of Instruments}

Resistance temperature devices (RTD) will be used to measure temperature in the block. A bundle of RTDs will be grouted with cement in temperature holes that are $3.8 \mathrm{~cm}$ in diameter. Some of the RTDs will be put in thin-walled stainless steel tubes so that they can be calibrated or replaced during the test. The Rapid Evaluation of $\mathrm{K}$ and Alpha (REKA) themal probe will be used to determine the thermal conductivity and thermal diffusivity [15]. Extensometers, displacement transducers, stress transducers, and acoustic emission transducers will be either grouted or mounted on a SEAMIST membrane in the geomechanical holes (both 7.6 and $3.8 \mathrm{~cm}$ in diameter). Humidity sensors (including resonant cavities and Humicap) and pressure transducers will be installed in a packer system in the moisture content hole $(7.6 \mathrm{~cm}$ in diameter). The mcisture content hole will also be used to measure air permeability. Microelectrode array sensors will monitor $\mathrm{pH}, \mathrm{Eh}, \mathrm{Cl}$-, and water sampling discs will be mounted on the outer surface of a SEAMIST membrane and pushed against the wall in the geochemistry holes (both 7.6 and $3.8 \mathrm{~cm}$ in diameter). Coupons of the waste package material, such as caton steel and copper, will also be instrumented with the chemical sensors and put in the geochemistry holes. The neutron logging 


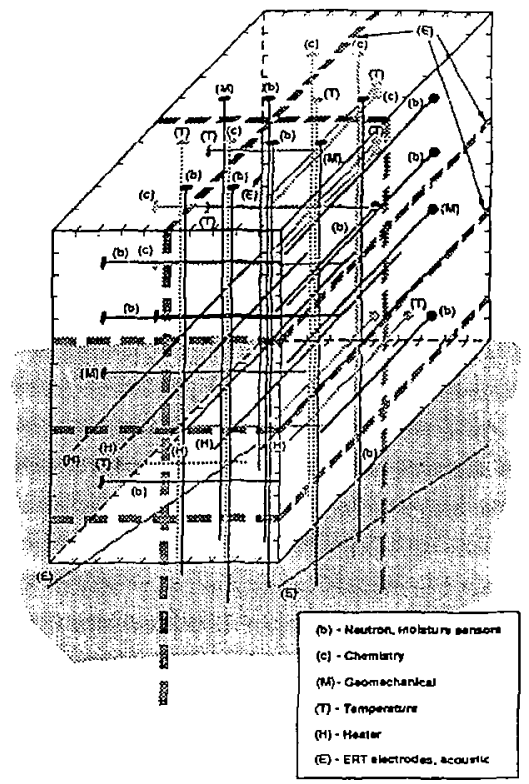

Figure 5. Instrumentation holes in the large block.

holes ( $3.8 \mathrm{~cm}$ in diameter) will be kept cpen by using a Teflon tubs !iner. The annular space between the liner and the borehole wall will be sealed with cement grout. One 2.44-m-long, 300watt heating element will be installed in each heater hole $(3.8 \mathrm{~cm}$ in diameter). Coupons of the waste package material will be put in the heater holes. The opening of the neater holes will be plugged to prevent heat loss and becoming a hydrological sink. ERT electrodes will be grouted in the ERT holes (both 7.6 and $3.8 \mathrm{~cm}$ in diameter).

In addition to the instruments in the holes, the following devices will be mounted on the block surface: a temperature control/moisture collecting system at the top, ERT eleztrodes, acoustic transducers, \&nd guard heaters (all on the sides of the block). The guard heaters will be used to maintain a boundary condition as close to adiabatic as possible.

After installation of the instruments and heaters, the block will be sealed with thermal and moisture barriers on its four sides. Bladders will be used to load the sides and the top of the block. The prefabricated load-retaining frame will be assembled around the block section by section. The electrical wires of instrument and high pressure lines will be brought out through pre-drilled holes in the load-retaining freme and also through trenches urider the frame. 


\section{(2) Tata Acquisition}

There are two data acquisition modes: automated data acquisition b; a data acquisition system (DAS) and manual da:a acquisition. The data to be actiuired by the DAS include temperature, pressure, displacement, wattage, voltage output from chemical sensors and Humicaps, etc. Data to be collected manually include neutron logging, REKA, resonant cavity, acoustic enuission and velocity, ERT, and air permeability. Water sampling will also be conducted manually.

\section{(3) Test Procedures}

The DAS will start collecting data at itast ore week before loads are applied to the block. The DAS wili continue throughout the test r. data will be obtained. Then the block will be loaded with a peak stress of about $4 \mathrm{MPa}$, bnth verically and horizonially, at ambient temperanure. At least onc set of the coanual data will be acquired when the block has reached an equilibrium to the loads. A.sso in this period, at least one set of stress-jtrain curves of the block will be obtained. Then ti: heaters within the block will be energized according to a pre-determined heating strategy, that will be determiized by scoping calculations, followed by a natural cosi-down period, in which the heaters are turned off. The bluck is considered cooled when its maximum iemperature decreases to within $5^{\circ} \mathrm{C}$ above the ambient temperature. The natural cool-down phase may take several months. During the heating phase, the temperature at the top of the block will be maintained at about $60^{\circ} \mathrm{C}$. The maximum temprature in the heater zone will be kept at about $135^{\circ} \mathrm{C}$. One of the criteria for determining the heating dyration, tile maximum temperature, and the temperature at the top of the block is to estahlish a dry-out region, a condensate region, ard a relatively undisturbed region si.nultaneously in the blcck for at least 2 months, so that enough data and samples can be acquired. During the heatin? phase, a constant load will be maintained on the block. The manual cata and water samp?es will be collected once every two weeks. Vapor that exits the thick will be coliected for measuring its amount and chemistry. The ext:mal loads on the block will be released when the block is cooled.

After the test the block will be mechanically dismantied so that the fracture surfaces and some portions of the matrix can be exanined for evidence or chemical processes and alterations due to the heating and cooling. Instruments that can be recovered will be re-calibrated.

\section{(4) Data Analyses}

Data reduction and azalysis will begin when the data are axaildble and will continue throughout the testing duration. The chemical effect of all man-made materials on the test will be studied and inrluded in the data analyses. 
Post-test model calculations will also be performed to analyze the test results. In this case V-TOUGH and NUFT will be used to model thermal-hydrological processes. The results of this experinent will also be used for model concept development and to verify model calculations using the therral-hydrological-chemical codes, such as EQ3/6, BASIN II, and PRECIP. A thermalmechanical model, such as Fast Lagrangian Analysis of Continua (FLAC), will be uscd to analyze the observed thermal-mechanical responses. A physical model will be set up to interpret the coupled processes.

\section{Current Status and Discussion}

The load-retaining steel frame is under construction. All vertical instrument holes have been drilled. Air injection tests indicate that the permeability of the block will be sufficient for generating a dry-out zone in the time frame of the experiment, based on the pre-test model calculations. Sawing to isolate the block was completed. The top of the block has been trimmed. Fractures on the top of the block have been mapped in detail. The excavation of the rocks surrounding ofe lange block is on-going. Smaller blocks are being cullected for tests to be conducted in the laboratory. Procurement of instruments is underway. Pre-test scoping calculations are teing conducted. A tentative schedule is to start the tests on the large block in February of 1995 .

The information obtained so far indicates that the LBT will provide an earlier (relative to EBSFT) opportunity for testing some numerical models used to understand the coupled TMHC processes. For model calibration and verification, the LBT has an unique advantage over in field testing in that the experimental conditions can be better controlled, easier three-dimensional accessibility to the test region occurs, and the test region (the block) can be berter characterized both before and after the testing.

\section{References}

[1]. Montazer, P. M., and W. E. Wilson (1984), "Conceptual hydrologic model of flow in the unsaturated zome, Yucca Mountain, Nevada," USGS-84-4345 Wuter Refources Inhestigative Report, U.S. Geol. Survey, Denver, CO. (NNA.890327.005I)

[2]. Ramirez, A. L. (1991), Prototype Engineerez'B Barrier Syssem Field Test (PEBSFT) Final Report, Lawrence Livermore National Laboratory, UCRL-ID-106159. (NNA. 910711.0047)

[3]. Buscheck, T. A., D. G. Wilder, and J. J. Nitao (1993), "Large-Scale In Siru Heater Tests for Hydrothermal Characterization at Yucca Mountain", in High Level Radioactive Waste Management, Proceedings of the Fourth Annual International Conference, Las Vegas, Nevada, 


\section{References}

[1]. Montazer, P. M., and W. E. Wilson (1984), "Conceptual hydrologic model of flow in the unsaturated zone, Yucca Mountain, Nevada," USGS-84-4345 Water Resources Investigative Repor, U.S. Geol. Survey, Denwer, CO. (NNA.890327.0051)

[2]. Ramirez, A. L. (1991), Prototype Engineered Barrier System Field Test (PEBSFT) Final Report, Lawrence Livermore National Laboratory, UCRL-ID-106159. (NNA. 910711.0047)

[3]. Buscheck, T. A., D. G. Wilder, and J. J. Nitao (1993), "Large-Scale In Situ Heater Tests for Hydrothermal Characterization at Yucca Mountain", in High Level Radioacive Waste Management, Proceedings of the Fourth Annual International Conference, Las Vegas, Nevada, April 26 - 30, 1993, American Nuclear Society, La Grange Park, IL, also Lawrence Livermore National Laboratory, UCRL-IC-112445. (NNA.930217.0046)

[4]. Daily, W. D., W. Lin, and T. Buscheck (1987), "Hydrological Properties of Topopah Spring Tuff: Laboratory Measurements," J. Geophys. Res., Vol. 92, No. B8, pp. 7854-7864. (NNA.900123.0064)

[5]. Daily, W. D., and Ramirez, A. L. (1989), "Evaluation of Electromagnetic Tomography to Map In Situ Water in Heated Welded Tuff," Water Resources Research, Vol. 25, No. 6, pp. 1083 1096. (NNA.910326.0097)

[6. Lin, W., A. L. Ramirez, and D. Watwood (1991,) "Temperature Measurements," Chapter 7 of Prototype Engineered Barrier Systen Field Test (PEBSFT) Final Report, A. L. Ramirez, Sci. Ed., Lawrence Livermore National Laboratory Livermore, CA, UCRL-DD-106159, pp. 82-93. (NNA.910711.0047)

[7]. Lin, W., and W. Daily (1989), "Laboratory Study of Fracture Healing in Topopah Spring Tuff - Implications for Near Field Hydrology," Proceedings of the Topical Meeting oin ^/uclear Waste Isolation in the Unsanurated Zone, Focks '89, American Nuclear Society, La Grange Park, IL. (NNA.900711.0241)

[8]. Lin, W., and W. Daily (1990), "Hydrological Properties of Topopah Spring Tuff under a Thermal Gradient - Laboratory Results," Int. J. Rock Mech. Min. Sci. \& Geomech. Abstr. Vol. 27, No. 5, pp. 373-385. (Readily Available) 
[9]. Lin, W. (1991), "Variation of Permeability with Temperature in Fractureo Topopah Spring Tuff Samples," in High Level Radioactive Waste Management, Proceedings of the Second Annual International Conference, Las Vegas, Nevada, April 28 - May 3, 1991, American Nuclear Society, La Grange Park, I, pp. 988-993. (NNA.910523.0105)

[10]. Lin, W. (1993), Technical Basis and Programmatic Requirements for I-arge Block Testing of Coupled Thermal-Mechanical-Hydrological-Chemical Processes, Lawrence Livermore National Laboratory, Livermore, CA, UCRL-D-1 12834. (NNA.930903.0075)

[11]. Zimmerman, R. M., and M. K. Blanford (1986), "Expected Thermal and Hydrothermal Environments for Waste Emplacement Holes Based on G-Tunnel Heater Experiments," in 27th U.S. Symposium on Rock Mechanics, H. Harman, Ed, (Society of Mining Engineers, Inc., Littleton, CO), pp. 874-882. (NNA.891212.0018)

[12]. Wilder, D. G. (1993), "Alternative Strategies - A Means for Saying Money and Time on the Yucca Mountain Project," in High Level Radioactive Waste Management, Proceedings of the Fourth Annual International Conference, Las Vegas, Nevada, April 26-30, 1993, American Nuclear Society, La Grange Park, II, pp. 1263-1270, also Lawrence Livermore National Laboratory, UCRL-JC-111652. (NNA.930224.0019)

[13]. Foltz, S. D., V. C. Tidwell, R. J. Glass, C. A. Kelsey, and R. R. Eaton (1992), "A: Experimental Investigation of Matrix Interaction on Fracture Flow," EOS Transact; ns, 1992, Fall Meeting, American Geophysical Union, San Francisco, CA, December 7-1, p.223. (A.bstractreadily available)

[14]. Tidwell, V. C., and R. J. Glass (1992), "X-ray and Visible Light Transmission as Twodimensional, Full-field Moisture-sensing Techniques: A Preliminary Comparison," High Level Radioactive Waste Management, Proceedings of the Third International Conference, April 12-16, 1992, American Nuclear Society, La Grange Park, Il, and American Society of Civil Engineers, New York, NY, pp. 1099-1110. (NNA.930205.0015)

[15]. Danko, G., and P. F. Mousset-Jones, (1991), "A Probe Method for Mcasuring In Situ Thermophysical Properies," in Proceedings, 2nd International High Level Radioactive Waste Management Conference, Las Vegas, NV, April 28-May 3, 1991, American Nuclear Society, La Grange Park, IL, pp. 555-563. (Readily Available) 